Int. J. Electrochem. Sci., 16 (2021) Article ID: 210436

International Journal of

ELECTROCHEMICAL

SCIENCE

www.electrochemsci.org

\title{
Corrosion Behaviour of Welded Steel Bars in Concrete with and without Cracks under Potentiostatic Conditions
}

\author{
Shicai Li, Zuquan Jin*, Xiaoying Zhang \\ Engineering Research Center of Concrete technology in marine environment, Ministry of Education, \\ Qingdao University of Technology, Qingdao 266033, China \\ "E-mail: jinzuquan@126.com
}

doi: $10.20964 / 2021.04 .61$

Received: 15 December 2020 / Accepted: 7 February 2021 / Published: 28 February 2021

Welding is a simple and effective way to connect steel bars in concrete structures. However, the high temperature during welding can affect the phase composition of the steel bars. In particular, when the welding part is located at the crack, it will be directly affected by corrosion ions, which will destroy the corrosion resistance and the durability of the steel bars. This study aimed to investigate the effects of welding on the corrosion behaviour of steel bars in concrete with and without cracks under potentiostatic acceleration. The corrosion time of the steel bar is shortened $48 \mathrm{~h}$ by welding, and the depassivation time of welded corrosion-resistant steel bars was approximately $18 \mathrm{~h}$ shorter than that of welded ordinary steel bars. In addition, the depassivation time of the welded steel bars and that of nonwelded bars in concrete was advanced by approximately $15 \mathrm{~h}$ and $14 \mathrm{~h}$, respectively, due to cracks. Because the progress of galvanic corrosion has been promoted, the influence is most significant when the type of welded steel bar is LC \& CR. For the welded LC \& LC types, the corrosion current density was increased by cracks.

Keywords: crack; concrete; welding; potentiostatic acceleration; corrosion behaviour

\section{FULL TEXT}

(C) 2021 The Authors. Published by ESG (www.electrochemsci.org). This article is an open access article distributed under the terms and conditions of the Creative Commons Attribution license (http://creativecommons.org/licenses/by/4.0/). 